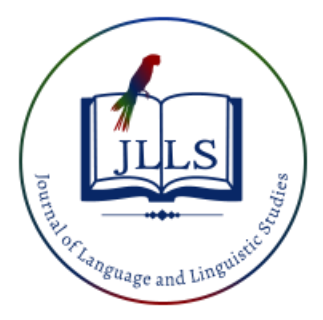

Available online at www.jlls.org

JOURNAL OF LANGUAGE

AND LINGUISTIC STUDIES

ISSN: 1305-578X

Journal of Language and Linguistic Studies, 17(1), 115-138; 2021

\title{
Anglicisms in Korean: A diachronic corpus-based study with special reference \\ to translation as a mode of language contact
}

\author{
Heekyung Choi a 1 iD \\ ${ }^{a}$ Hankuk University of Foreign Studies, Seoul, Republic of Korea
}

\section{APA Citation:}

Choi, H. (2021). Anglicisms in Korean: A diachronic corpus-based study with special reference to translation as a mode of language contact. Journal of Language and Linguistic Studies, 17(1), 115-138. Doi: 10.52462/jlls. 7

Submission Date: 10/01/2021

Acceptance Date: 16/03/2021

\begin{abstract}
This study examines how English has penetrated the Korean language by analyzing Anglicisms in weekly news magazine articles, with special reference to translation as a mode of language contact. For this purpose, it conducts a diachronic quantitative analysis of the occurrence of Anglicisms by compiling and utilizing corpora consisting of translated and original Korean news magazine articles over a period of 20 years. The results of this analysis are explained through a qualitative analysis of sociolinguistic factors influencing contact-induced language change. The findings suggest that Anglicisms increased over the 20 years at a greater pace in original texts than in translated ones. Various sociolinguistic factors, including language ideology, language policy, and linguistic attitude, affected the results either positively or negatively. Besides, translators, as key agents of language contact, seem more conservative than other native speakers in changing their attitude toward Anglicisms, partly due to the complex decision-making process of translation. These results help broaden the scope of translation studies by introducing a new contact linguistic perspective.
\end{abstract}

Keywords: Anglicism; language ideology; translation as a mode of language contact; diachronic corpus analysis; journalistic texts

\section{Introduction}

When two or more languages come into contact, they may undergo linguistic changes induced by contact. Today, due to the overwhelming prestige and power of English in business, culture, politics, education, and other domains of society, Englishization has become a global phenomenon. English even enjoys the status of an official language in many sectors where cross-lingual communication is of significance (Gotti, 2007, pp. 143-144; Pennycook, 2009, p. 113). Its spread has significantly affected not only international exchange and communication but also each society's native language (Trask \& Stockwell, 2007, p. 137). Korea is not an exception to this trend. The Korean language and its speakers have been greatly influenced by English, whose words, phrases, or even sentences are frequently observed in written and spoken language across society, notably in public media, including

\footnotetext{
${ }^{1}$ Corresponding author.

E-mail address: choihk@hufs.ac.kr
} 
newspapers, magazines, TV shows, and advertisements (Baratta, 2014; Jung, 2001; Kim, 2016; Lee, 2014).

The incorporation of English into Korean can be observed in not only original Korean texts but also translated texts, which account for a considerable share of the entire Korean linguistic reservoir. Translation is a unique site of language contact, involving a source language and a target language with the translator being a "contact agent" between the two. In today's world, language contact is more intense and direct than ever even between geographically and typologically distant languages such as Korean and English because of increased travel, mass media, and the Internet. However, translation still serves as a primary channel to facilitate communication across different cultures and languages. Translation and translators arguably influence the linguistic behavior of a whole language community, not just individual speakers, in that they often serve as an effective conduit to enable the introduction of new concepts, ideas, technologies, and knowledge to the receptor language or society. This is often the case with translation where English is the source language. Translations from English, the de facto lingua franca, into other languages are overwhelmingly greater than those from other languages into English (Bielsa \& Bassnett, 2009, p. 28).

Against this backdrop, this study investigates English "fingerprints" (Gellerstam, 2005) observed in English-to-Korean translations compared to original Korean texts, particularly in weekly news magazine articles. Previous research has extensively explored the influence of English on Korean, and several studies have discussed the topic at various linguistic levels (Ahn, 2018; Baik, 1994; Harkness, 2012; Kim, 2016; Oh, 2012). However, except for a few small-scale studies on Anglicisms (Choi, 2018), Englishization in translated Korean texts has been either rarely examined as a separate topic in linguistics or often approached as a translation method (Cho, 2014; Kim \& Kim, 2011; Ryu, 2007) or in terms of "translationese" (a derogative expression referring to awkward, unnatural, or unidiomatic translation). Existing translation studies have mainly focused on translation per se; the nature of translation as a form of language contact has not yet been adequately explored. The fact that translation is part of the entire linguistic output and that translators are a subset of a language community representing unique linguistic behavior has received limited attention from academia. This has been noted in prior research. Bielsa (2012, pp. 19-20) indicated that translation has merely been regarded as a tool to transfer linguistic and cultural elements, which neglects the active role of translators as contact agents using their strategies and interventions to influence relations between languages and cultures.

This study focuses on the phenomenon of English borrowing at the lexical level. Considering that it is regarded as the first stage at which interlingual borrowing occurs (Baumgarten \& Özçetin, 2008; Hilgendorf, 2001; Sankoff, 2001; Siemund, 2008), the lexical level may be the right place to begin a discussion on the influence of English on Korean, as the two languages are typologically distant from each other. The present study attempts to clarify the lexical influence of English on Korean, or Anglicisms, through translated and original Korean news magazine articles, focusing on the following relevant factors promoting borrowing: sociolinguistic factors driving contact-induced linguistic change, and variables related to translation and translators. It further aims to explore the diachronic change in the acceptability of Anglicisms over 20 years, as "time" is a key factor that stimulates language change (De Saussure, 1966, p. 78).

\section{Language contact and change: The case of English and Korean}

\subsection{Lexical borrowing and its causes}

A language community unaffected by interlanguage encounters is historically unprecedented (Hickey, 2010, p. 7). The language contact situation and its impact can vary from direct interpersonal 
contact to indirect contact through technical and cultural media (Gottlieb, 2005, p. 161). Since Korean and English are typologically distant languages belonging to different language families (Dalby, 2004), the contact between the two can be considered a case of two stable and geographically distant language communities meeting each other through human interactions and via multiple media. The changes resulting from such language contact are almost always related to the phenomenon of language maintenance, namely borrowing and code-switching (Winford, 2003), and the former is the main topic of this study.

Borrowing refers to incorporating elements of one language into another; these elements are mainly loanwords, but in rare cases, phonetic or grammatical structures can also be borrowed (Crystal, 2008, p. 58). Such structural borrowing does not occur without lexical borrowing (Thomason \& Kaufman, 1988, pp. 20-21). Winford (2003, p. 12) similarly defined it as a phenomenon wherein a language community's first language is subject to lexical and structural influences from an external language in contact. In general language contact situations, borrowing starts at the lexical level and affects grammatical units only much later (Baumgarten \& Özçetin, 2008; Gómez-Rendón, 2008; Hilgendorf, 2001; Sankoff, 2001; Siemund, 2008). Its extent and intensity depend largely on the strength and time of contact, the population of bilingual speakers, political and social influence, and the typological proximity between languages in contact (Thomason \& Kauffman, 1988, pp. 72-76). Since the two typologically distant languages have had a relatively short period of contact, it is reasonable to argue that borrowing between Korean and English is at the initial stages of the borrowing scale proposed by Thomason and Kaufman (1988, pp. 74-76) - borrowing vocabulary and some structural elements. In this sense, Anglicism - defined as "a word or idiom that is recognizably English in its form (spelling, pronunciation, morphology, or at least one of the three), but is accepted as an item of the vocabulary of the receptor language" (Görlach, 2003, p. 1) -rightly refers to lexical borrowing between English and Korean that this study attempts to investigate.

The degree of change resulting from language contact varies, from simply borrowing vocabulary to creating a new language, depending on linguistic and social factors (Winford, 2003, p. 2). The same is true for the contact between English and Korean. The language contact outcomes observed in the Korean language can also be attributed to a combination of numerous factors. Gómez-Rendón (2008) attempted to describe the causes of borrowing in a stratified manner. His explanatory model refers to motivations, factors, and conditions as primary, secondary, and tertiary causes for borrowing, respectively. It classifies each tier into positive and negative causes as well as linguistic and sociolinguistic causes. First, motivations include social, regional, and communicative causes that exert non-linguistic influence. They not only affect secondary and tertiary causes but also cause language changes in their own right. Second, factors are divided into sociolinguistic or linguistic. They cannot exert influence by themselves but do so only in interaction with motivations, promoting or inhibiting contact-induced language change. Lastly, conditions are also categorized into linguistic and sociolinguistic ones, and they cannot induce change independently of motivations or factors (GómezRendón, 2008, pp. 31-44). Figure 1 presents the sociolinguistic causes of the three tiers, as suggested in Gómez-Rendón's hierarchical model. 


\begin{tabular}{|c|c|c|}
\hline $\begin{array}{c}\text { Primary } \\
\text { (Motivations) }\end{array}$ & $\begin{array}{c}\text { Secondary } \\
\text { (Factors) }\end{array}$ \\
\hline $\begin{array}{c}\text { Social: cultural, economic, } \\
\text { identity, ethnic awareness, } \\
\text { etc. } \\
\text { (Conditions) }\end{array}$ \\
$\begin{array}{c}\text { Geographical: areal, } \\
\text { geographical, demographic } \\
\text { Communicative: discursive, } \\
\text { pragmatic, communicational }\end{array}$ & $\begin{array}{c}\text { Sociolinguistic: attitudes, } \\
\text { perceptions, ethnolinguistic } \\
\text { loyalty, prestige, etc. }\end{array}$ & $\begin{array}{c}\text { Sociolinguistic: age, gender, } \\
\text { education, occupation, or } \\
\text { mobility of speakers }\end{array}$ \\
\hline
\end{tabular}

Figure 1. Sociolinguistic causes of contact-induced language change (a revised version of the figure included in Gómez-Rendón, 2008, p. 35)

In accordance with other previous studies, Gómez-Rendón asserted that non-linguistic contexts are the ultimate causes of contact-related language change, positing that they take precedence over linguistic causes at all levels of his model. According to Thomason (2001, pp. 21-22), social factorsnot linguistic ones such as structural similarities - are the critical causes that should be considered concerning contact-induced language change. For instance, language change can be affected by whether speakers view their first language as the identity of their people or how much loyalty they show to the language. It is unclear whether such linguistic awareness induces a person's specific linguistic behavior; however, there is no doubt that a speaker's attitude and the cause of language change are somehow correlated with each other. As Nelde (1992, p. 132) indicated, language contact is not only a social issue but also an individual one. Therefore, psychological and social factors can also work together in affecting language contact outcomes. This is the focus of this study, which examines the causes of lexical borrowing not only at the social level but also at the individual level with respect to translators who act as contact agents.

However, Gómez-Rendón's (2008) explanatory model is not a precise and exhaustive scientific model. There are overlaps across the abovementioned three tiers, blurring the divide and causing ambiguity. Nevertheless, the model is worthwhile in that it indicates that numerous macro and micro factors influence the process of borrowing. Furthermore, it is designed as a general model of language contact and change, specifically applicable to language borrowing (Gómez-Rendón, 2008, p. 31); therefore, it can also be applied to analyze lexical borrowing resulting from contact between English and Korean. It can serve as a starting point for structured or focused explanatory analyses. In this study, the qualitative analysis is based on the non-linguistic causes presented in Gómez-Rendón's model. This is because some linguistic factors are not valid for the contact between the two typologically distant languages, Korean and English and because non-linguistic factors are considered the ultimate causes of contact-induced language change.

\subsection{English ideology in Korea}

Silverstein $(1979$, p. 193) defined language or linguistic ideologies as "any sets of beliefs about language articulated by the users as a rationalization or justification of perceived language structure and use." This definition goes beyond simply referring to a system of beliefs, including evaluative (rationalization or justification) and behavioral (language structure and use) components, which are key elements of an ideology, as claimed by Fine and Sandstrom (1993, p. 24). Silverstein's definition is useful in the present discussion because a set of beliefs connected to linguistic attitudes and evaluations of a language can eventually lead to the actual spoken or written usage of the language (Karakaş, 2017). Moreover, language ideology is closely related to power. Fairclough (1989, pp. 2-3) argued that in modern society, the ideological action of language is an important means of exercising 
power; researchers interested in power relations should focus on language use. This is also relevant for an international language; as Crystal (2003, p. 9) mentioned, "a language has traditionally become an international language for one chief reason: the power of its people." Considering the presence and influence of English worldwide, such views are not exaggerations. Historically, Greek and Latin have demonstrated this view. More recently, English has become a major driving force in creating a class of intellectual power in many areas of society, with unprecedented social and ideological presence (Kachru, 1990). Indeed, language ideology is "a cognitive framework that constructs relationships of power deeply fundamental to society through the semiotics of language" (Park, 2009, p. 15). According to this view, in a society with English language ideology, English speakers are highly likely to have power and be at a relative advantage in terms of communication. Learning English can provide access to equal opportunities and better communication. At the same time, English can serve as a class dialect that grants exclusive authority to a specific group, culture, or knowledge system (Gotti, 2007; Görgülü, 2018; Pennycook, 2009).

English language ideology directly or indirectly affects the linguistic behavior and attitude of a language community that embraces English. However, before arguing that the receptor language speakers blindly accept the dominant power of English, it is critical to understand how they view English as a target of utilization or resistance and attempt to "reconstruct their languages, cultures, and identities to their advantage" (Pennycook, 2009, p. 117). Park (2009, pp. 2-4) contended that the dominant position of English in Korea is partly due to Koreans' linguistic ideology toward English. However, he also indicated that the English language ideology in Korea consists of three subideologies. First, English is an economically, culturally, and politically essential language that must be acquired in the era of globalization. Second, since English is not "mine" but that of "others," accepting it denies Korea's unique identity, so Koreans must resist English. Third, despite their dedication to English education, Koreans are perceived to lack English proficiency (Park, 2009, p. 26). According to Park's argument, although English is dominant in Korea, these sub-ideologies may manifest themselves in different linguistic attitudes and behaviors. In other words, there may be complicated combinations of active acceptance, linguistic purism (or language purification), avoidance, and jealousy or criticism of English used in Korean society. It is thus necessary to avoid adopting a fragmentary perspective to Korean society's language ideology or perception toward English. The greater the influence of English language ideology, the more intense the reactions to it, either positive or negative. As Park (2009) convincingly stated, both pro-and anti-English factions contribute to the development of English ideologies in a receiving country.

A society's language ideology is the sum of individual language users' linguistic consciousness and attitudes; however, once the ideology is established to a certain extent, it influences the individual members of society. As explained in Gómez-Rendón's (2008) model, contact-induced language change can be affected by numerous factors at different levels; linguistic changes occurring in the whole language community and those in its specific sub-communities may not necessarily be the same. For example, in the case of translated texts, the context of language contact and those participating in it are more specific than general, so the factors and patterns of contact-related language change may be different. This is further discussed in Section 4.

\subsection{Translation as a site of language contact}

From the perspective of language contact and change, translation is both a process and by product of contact between two languages through translators' intermediary behavior. Translators are agents of language contact working not for themselves but for stakeholders such as readers and clients. However, they are also members of the whole language community and are influenced by the prevailing language ideology in the community. Thus, when translators translate texts into their first 
language, the translation has the characteristics of not only the target language in specific contexts but also the general language of the translators' language community. In addition, both the general norms of language use and translation norms affect translators' linguistic behavior during the contact process. Translators' linguistic choices and decisions should therefore be reviewed because of the special context of language contact. For instance, lexical borrowings observed in translated texts are a result of translators' choices in the language community as well as in a specific translation context, which are affected by various factors on both sides. Since translated texts are intended to distribute and share information and knowledge throughout society, translators' linguistic borrowings resulting from their choices and decisions ultimately affect the world outside the texts. As Wollin (2002, p. 514) rightly indicated, "translation has taken part... in developing vernacular language through foreign patterns," and its influence can be "regarded as a channel of foreign linguistic influence in general."

Considering that translation is a form of language contact and represents a significant proportion of text production in many language communities, research on translation and language change is important (Teich, 2009). In particular, lexical borrowing has been a prominent topic in translation studies, although discussions on the topic have been limited to exploring borrowing as a translation technique used for a new concept or vocabulary item lacking in the target language. However, borrowing is not intended to simply fill a gap (Matras, 2010, pp. 82-83). The functional translation theory (Holz-Mänttäri, 1984), which focuses on the social relations surrounding translation behavior, indicates that translators make decisions through a complex process involving factors other than textual or linguistic factors. Moreover, since translators are also members of society, their degree of acceptance of, or receptivity to, borrowing may also be influenced by sociocultural and sociolinguistic factors. Since translation itself is a field of language contact, Gómez-Rendón's (2008) model (Figure 1 ) is useful for systematically examining the factors that induce borrowing among translators. Figure 2 shows a revised model of that presented in Figure 1 in the context of English-to-Korean translation. As per the original model, the three types of causes work in a dynamic and complex way (GómezRendón, 2008, p. 34), which is also the case for the revised model. For example, English ideology, a primary cause, is closely related to the phenomenon of preference for English, which facilitates Englishization, a secondary cause, and can affect the meta-discourse on language policy, language norms, and Anglicisms. English ideology and globalization, being primary causes, can also interact with English education intensity, a tertiary cause.

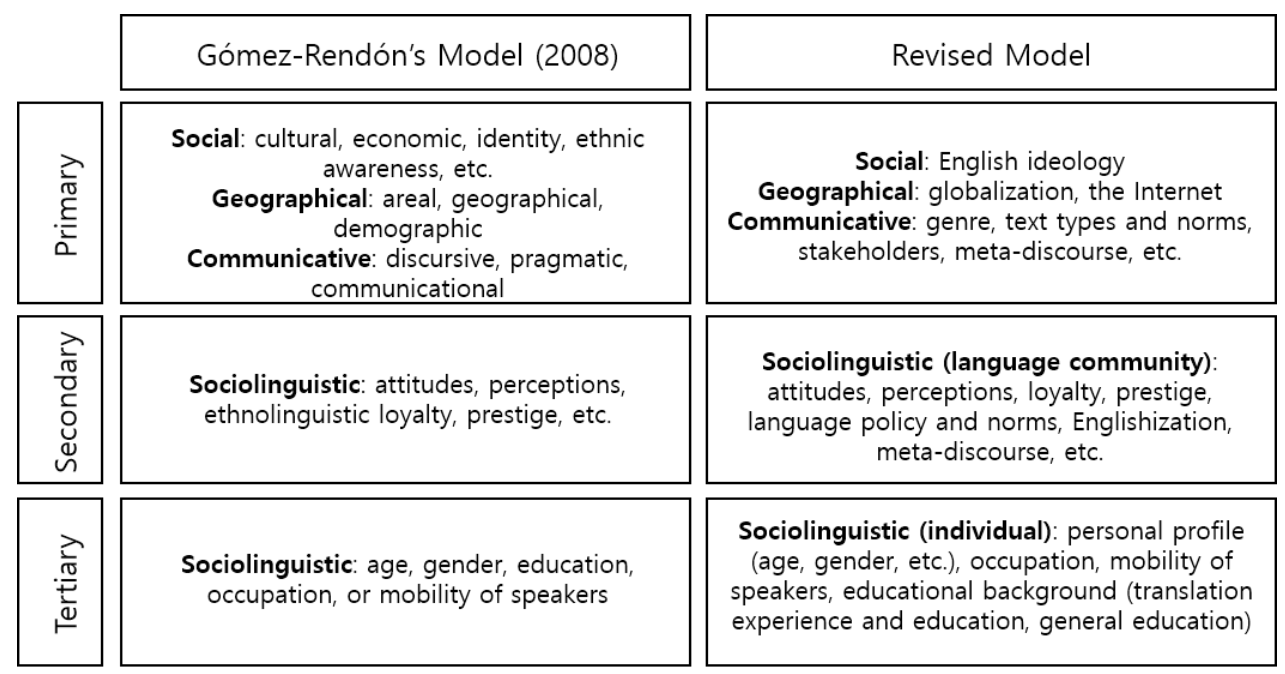

Figure 2. A revised version of Gómez-Rendón's (2008) model for borrowing in translation contexts 


\section{Methodology}

This study addresses the following research questions: (1) How does the use of Anglicisms in English-to-Korean translations compare to their use in original Korean texts and how has such use diachronically changed? (2) What are the possible reasons for the use of Anglicisms? To answer these questions, this study first descriptively quantified the use of Anglicisms in translated and nontranslated original texts. Next, the possible reasons for their use were investigated in the context of both translation and Korean society. The second part of the analysis is essential because the sociolinguistic environment and factors in both contexts likely influence translators' and general speakers' decision-making process related to lexical borrowing.

\subsection{Data and corpora}

Data were selected based on the following criteria. First, data should be written, not spoken, as this study investigates translated and original texts as a site of language contact. Second, the selected texts should influence popular language use. As social influence is necessary for language change (De Saussure, 1966, p. 78), the more widely read the texts in a language community, the better. Third, there should be enough English texts and their Korean translations and original Korean texts of the same genre and type to build parallel and comparable corpora. Last but not least, the time span of data should be at least 20 years. Prime examples of texts that meet these criteria include printed and online written media, such as magazine and newspaper articles, which have a greater linguistic influence on the public (Jung, 1998, p. 44; Millar, 2009, p. 194). It is necessary to focus on the media's receptiveness to English to understand how Anglicisms are received by Koreans because the media are the main channels for foreign language contact (Kim, 2006, p. 51). In addition, magazines and newspapers are suitable data sources for such corpora because it is relatively easy to understand the topics of their articles by their titles and because they have similar readerships (Laviosa, 2002, pp. 3940).

A corpus of 600 articles (463,047 words) was built from news magazines-Newsweek and its Korean translation and Sisa Journal as its native Korean counterpart-from two time periods spanning 20 years. Newsweek is a representative weekly news magazine in the United States with a history of more than 80 years. The Korean version of Newsweek had been in publication for almost 30 years after its first issue in November 1991, until its publication was suspended in December 2019. As for the non-translated original Korean texts as a comparable corpus, Sisa Journal, ranked in the top tier in terms of circulation and readership (at the time of data collection), was selected. As carrying out an objective comparison between translated and non-translated texts is critical, the selected articles were carefully chosen considering the balance and composition of content in each corpus.

To build a parallel corpus of English texts and their translations, 100 articles were sampled from Newsweek's English and Korean versions, respectively, from November 1991 to October 1992 and another 100 articles from November 2011 to October 2012. The period of the two datasets was 20 years, during which significant socio-environmental changes related to language contact and change occurred. From the late 1990s to the early 2000s, when high-speed Internet spread to businesses and homes in Korea, Koreans, including translators, gained more direct and frequent access to English. As such changes created an environment favoring increased use of loanwords (Crystal, 2001; Hedderich, 2003; Kvaran, 2004), conducting a diachronic analysis of English lexical borrowings in this period is worthwhile. Since the composition and theme of Newsweek articles changed slightly over this period, both past and recent data were equally sampled from similar subject areas (technology, political affairs, economy, international affairs, environment, health, business, social culture, life science, interviews, science, sports, and US Affairs). The comparable corpus constructed from Sisa Journal 
articles was organized similarly by examining the articles' categories and titles. Table 1 provides an outline of the corpus composition and content.

Table 1. Corpus composition and content

\begin{tabular}{c|c|c|c|c}
\hline Corpus Type & Language & Corpus Name & Time Period & Size (words) \\
\hline \multirow{3}{*}{ Parallel } & \multirow{2}{*}{ English } & ST_Eng_1 & $1991-1992$ & 100 articles (100,067) \\
\cline { 3 - 5 } & & ST_Eng_2 & $2011-2012$ & 100 articles $(105,435)$ \\
\cline { 2 - 5 } & \multirow{2}{*}{ Korean } & TT_Kor_1 & $1991-1992$ & 100 articles $(54,654)$ \\
\cline { 3 - 5 } & & TT_Kor_2 & $2011-2012$ & 100 articles $(72,642)$ \\
\hline \multirow{2}{*}{ Comparable } & \multirow{2}{*}{ Korean } & OT_Kor_1 & $1991-1992$ & 100 articles $(67,251)$ \\
\cline { 3 - 5 } & & OT_Kor_2 & $2011-2012$ & 100 articles $(62,998)$ \\
\hline
\end{tabular}

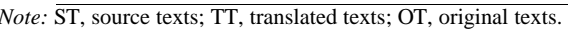

\subsection{Methods}

As described earlier, the entire dataset was arranged into two parallel corpora of English source texts (ST) and Korean translated texts (TT) and two comparable corpora of original texts (OT) in Korean for the two time periods. The data analysis framework consisted of two complementary methods: descriptive and explanatory. In the descriptive analysis, the corpora were quantitatively examined for the use of Anglicisms in the texts; examples of Anglicisms are discussed below. In the explanatory analysis, key descriptive analysis findings were qualitatively reviewed to identify the possible reasons for the use of Anglicisms based on the revised model of Gómez-Rendón (2008) (Figure 2). The analysis was conducted both synchronically between translated and original Korean texts in the same period and diachronically between the two periods.

\section{Corpus Analysis}

\subsection{Corpus overview}

\subsubsection{Basic statistics of the corpus}

In this subsection, the basic statistics of the entire corpus are presented. Table 2 shows the number of types (distinct words) and tokens (running words) per corpus. When the size of the past (ST_Eng_1 and TT_Kor_1) and recent data (ST_Eng_2 and TT_Kor_2) in the parallel corpora was compared, it was found that ST_Eng_1 and ST_Eng_2 were similar in size, whereas the TT corpora were considerably different. This can be accounted for to some extent by comparing individual texts of the ST and TT corpora. In both past and recent data, although each article was supposed to be entirely translated in principle, it was found that parts (phrases, sentences, or even paragraphs) that were not directly related to an article's core information were omitted in the past data more often than in the recent data. Moreover, if there were several follow-up articles attached to the main article on the same subject, only some of them were translated in some cases in the past data. Although this does not seem to pose a problem for this study, it has nevertheless been mentioned here to prevent any confusion about the sizes of the corpora and to exemplify the complex decision-making process of translation. 
Table 2. Basic statistics of the corpus

\begin{tabular}{ccccccc}
\hline Statistics & ST_Eng_1 & ST_Eng_2 & TT_Kor_1 & TT_Kor_2 & OT_Kor_1 & OT_Kor_2 \\
\hline Types & 13,409 & 12,767 & 25,193 & 29,524 & 29,764 & 25,091 \\
Tokens & 100,067 & 105,435 & 54,654 & 72,642 & 67,251 & 62,998 \\
\hline Note: ST, source texts; TT, translated texts; OT, original texts.
\end{tabular}

\subsubsection{Transition in the transcription system and language ideology}

In TT and OT, there were several implications related to the intuitively observed text characteristics. First, there were changes in the language transcriptions of Newsweek's Korean version and Sisa Journal over the 20 years. In addition to the original Korean alphabet or Han-geul (한글), Chinese characters, or Han-ja (漢字, 한자), and English alphabet appeared in both TT and OT. Table 3 summarizes the number of English and Chinese types and tokens and their ratios to the total numbers.

Table 3. Number of English and Chinese types and tokens, and their ratios

\begin{tabular}{ccccc}
\hline Statistics & TT_Kor_1 & TT_Kor_2 & OT_Kor_1 & OT_Kor_2 \\
\hline Total types & 25,193 & 29,524 & 29,764 & 25,091 \\
Total tokens & 54,654 & 72,642 & 67,251 & 62,998 \\
English types (\%) & $374(1.48 \%)$ & $721(2.44 \%)$ & $302(1.01 \%)$ & $516(2.06 \%)$ \\
English tokens (\%) & $689(1.26 \%)$ & $1,099(1.51 \%)$ & $528(0.79 \%)$ & $1,211(1.92 \%)$ \\
Chinese types (\%) & $733(2.91 \%)$ & $37(0.13 \%)$ & $169(0.57 \%)$ & $54(0.22 \%)$ \\
Chinese tokens (\%) & $851(1.56 \%)$ & $40(0.06 \%)$ & $185(0.28 \%)$ & $59(0.09 \%)$ \\
\hline
\end{tabular}

In the past TT and OT, the use of Han-ja was noticeable, whereas, in the recent data, it was rarely used, except in parentheses along with Korean words to clarify the semantic origin of the words. There were particularly notable changes in TT compared to OT. In the past data, Han-ja was used more frequently than English, whereas in the recent data, its presence was much less than that of English, so less as to be insignificant. The use of Han-ja in Korean writings was relatively common in the past. Even Korean translations of English magazine articles used them often, suggesting the significant influence of Chinese culture and language on Korean society. The Korean version of Newsweek, as a mass medium, seems to have followed the norms of published language at that time, under which Chinese characters in formal writing were readily tolerated. The minimum proportion of Han-ja transcriptions in the recent data, both in translated and non-translated texts, implies the occurrence of a significant shift in the acceptance of Chinese characters by the Korean language community between the two periods. Such a shift may also have accompanied transitions in linguistic and textual norms in the media.

Regarding English transcriptions, it is difficult to infer such a change from the numerical values shown in Table 3. Although the numbers are larger in the recent data, the difference is not significant. However, focusing on the comparison between TT and OT is worthwhile. One may be inclined to assume that translated Korean texts likely contain more words spelled in English than original Korean texts because of the influence of the English ST. Table 3 shows that this assumption is generally valid across corpora. However, when comparing TT and OT in the recent data, the ratio of English types was larger in TT, while that of English tokens was greater in OT. In other words, the rate of occurrence of English-spelled words in the recent data was higher in non-translated texts than in 
translated ones. This shows that the influence of the English ST may not be the only factor determining the intensity of English lexical borrowing, suggesting that other factors, such as language environment and norms, as well as authors, translators, and readers, may also influence the borrowing process in translation.

The change in Chinese and English transcriptions observed in TT and OT reflects the transition in Korean society from a mixed-script system of Han-geul and Han-ja to another mixed system of Hangeul and English (Kim, 2008, p. 479). These two linguistic ideologies seem to have influenced this transition. Amid globalization, English ideology spread to Korea, while at the same time, a postChinese ideology was developing during the study period. Throughout Korean history, Chinese script has been widely used as a transcription system. Chinese characters provided the foundation for "Korean people to create and enrich their language, culture, and history" for two millennia (Kim, 2009 , p. 189), contributing to the establishment of a deep-rooted language ideology. However, after liberation from Japan's colonial rule in 1945, Korea's language policy recognized the use of Chinese characters as the most urgent problem to be solved, along with the problem of Japanese residuals embedded in the Korean language. After the establishment of the government, in 1948, the Han-geulonly policy was enacted, regulating that all public documents should be written in Han-geul. Nevertheless, the law stipulated that Chinese characters could also be used when necessary, indicating that Chinese ideology was still steadfast in Korea. This is demonstrated by the mixed-use of Han-ja observed in this study's corpora.

Meanwhile, the movement to purify the Korean language continued; in 1991, the National Institute of Korean Language (NIKL) was established, and it began to implement national language policies in earnest. The Framework Act on the Korean Language, enacted in 2005, further strengthened the Hangeul-only policy. Article 14 of this Act states the following: "Public institutions, etc. shall prepare official documents in the Korean language in accordance with language norms, using terms and sentences which ordinary citizens easily understand: Provided, That Chinese characters or other foreign letters may be entered in parentheses, in cases prescribed by Presidential Decree." It thus put specific restrictions on the use of Han-ja. Besides, Article 15 stipulates the following: "Mass media such as newspapers, broadcasting, magazines, or the Internet shall endeavor to contribute to the people's appropriate use of the Korean language." General language norms were thus proposed for media texts, such as Newsweek. The restrictions on foreign characters imposed by the Act also apply to other foreign scripts, including the Roman alphabet; however, although the use of Chinese characters significantly reduced in the early 2010s according to this study's data, the use of English script increased from the early 1990s to the early 2010s. This can be attributed to the rapid spread of Hangeul and English ideologies throughout Korean society over the past 20 years, apart from the influence of language policy and norms, which significantly weakened Chinese ideology. This transition in language ideology seems to have subsequently affected the language norms of weekly magazines in both translated and original writing.

\subsection{Quantitative analysis of Anglicisms}

This subsection presents the synchronic and diachronic analysis and comparison of the corpora through the identified quantitative characteristics of Anglicisms in TT and OT. In addition, the quantitative analysis results are explained with their possible causes based on the revised borrowing model (Figure 2).

\subsubsection{Classification of Anglicisms in the corpus}

First, all kinds of Anglicisms were collected from the Korean corpora (TT and OT) in accordance with Görlach's (2003, p. 1) definition of Anglicism mentioned in Section 2. The total occurrences of 
Anglicisms were then classified based on the language of origin, transcription system, and combinations of lexical elements, as shown in Table 4.

Table 4. Classification of Anglicisms in the corpus

\begin{tabular}{|c|c|c|c|c|c|}
\hline $\begin{array}{c}\text { Language } \\
\text { of origin }\end{array}$ & $\begin{array}{c}\text { Transcription } \\
\text { system }\end{array}$ & $\begin{array}{l}\text { Combinations of } \\
\text { lexical elements }\end{array}$ & No. & Examples & Meaning \\
\hline \multirow{5}{*}{ English } & \multirow{2}{*}{ English } & $\begin{array}{l}\text { English word (as an } \\
\text { initialism) }\end{array}$ & 1 & MMF & $\begin{array}{l}\text { a money market } \\
\text { fund }\end{array}$ \\
\hline & & $\begin{array}{l}\text { English word (as an } \\
\text { acronym) }\end{array}$ & 2 & NATO & $\begin{array}{l}\text { the North Atlantic } \\
\text { Treaty Organization }\end{array}$ \\
\hline & \multirow[b]{2}{*}{ Korean } & English word & 3 & 글로벌 [geul-lo-beol] & global \\
\hline & & $\begin{array}{l}\text { English word + English } \\
\text { word }\end{array}$ & 4 & $\begin{array}{c}\text { 비즈니스 스쿨 [bi-jeu-ni- } \\
\text { seu seu-kul] }\end{array}$ & a business school \\
\hline & $\begin{array}{l}\text { English, } \\
\text { Korean }\end{array}$ & $\begin{array}{c}\text { English word + English } \\
\text { word }\end{array}$ & 5 & TV 프로 [TV-peu-lo] & a TV program \\
\hline \multirow{2}{*}{$\begin{array}{l}\text { English, } \\
\text { Korean }\end{array}$} & \multirow{2}{*}{ Korean } & $\begin{array}{l}\text { English word + Korean } \\
\text { affix }\end{array}$ & 6 & $\begin{array}{c}\text { 데이트하다 [de-i-teu-ha- } \\
\text { da] }\end{array}$ & to date (as a verb) \\
\hline & & $\begin{array}{c}\text { English word + Korean } \\
\text { affix }\end{array}$ & 7 & $\begin{array}{c}\text { 업그레이드되다 [eob- } \\
\text { geu-le-i-deu-doe-da] }\end{array}$ & to be upgraded \\
\hline \multirow{7}{*}{$\begin{array}{l}\text { English, } \\
\text { Chinese }\end{array}$} & \multirow{5}{*}{ Korean } & $\begin{array}{l}\text { Sino-Korean word + } \\
\text { English word }\end{array}$ & 8 & $\begin{array}{c}\text { 신용카드 [sin-yong-ka- } \\
\text { deu] }\end{array}$ & a credit card \\
\hline & & $\begin{array}{c}\text { Sino-Korean word }+ \\
\text { English word + Sino- } \\
\text { Korean word } \\
\end{array}$ & 9 & $\begin{array}{l}\text { 국제스포츠연맹 [gug-je- } \\
\text { seu-po-cheu-yeon-maeng] }\end{array}$ & $\begin{array}{c}\text { an international } \\
\text { association of sports }\end{array}$ \\
\hline & & $\begin{array}{l}\text { English word + Sino- } \\
\text { Korean word + English } \\
\text { word }\end{array}$ & 10 & $\begin{array}{c}\text { 실버인재센터 [sil-beo-in- } \\
\text { jae-sen-teo] }\end{array}$ & $\begin{array}{l}\text { a job center for the } \\
\text { elderly }\end{array}$ \\
\hline & & $\begin{array}{c}\text { Sino-Korean word + } \\
\text { English word + Sino- } \\
\text { Korean affix } \\
\end{array}$ & 11 & $\begin{array}{c}\text { 동유럽권 [dong-yu-leob- } \\
\text { gwon] }\end{array}$ & $\begin{array}{l}\text { the Eastern Europe } \\
\text { region }\end{array}$ \\
\hline & & $\begin{array}{c}\text { English word + Sino- } \\
\text { Korean affix } \\
\end{array}$ & 12 & 서비스료 [seo-bi-seu-lyo] & a service charge \\
\hline & $\begin{array}{l}\text { English, } \\
\text { Korean }\end{array}$ & $\begin{array}{c}\text { English word (as an } \\
\text { initialism) + Sino-Korean } \\
\text { affix }\end{array}$ & 13 & LTE 망 [LTE-mang] & an LTE network \\
\hline & $\begin{array}{l}\text { Korean, } \\
\text { Chinese }\end{array}$ & $\begin{array}{l}\text { English word + Sino- } \\
\text { Korean affix }\end{array}$ & 14 & 타임스紙 [ta-im-seu-ji] & $\begin{array}{c}\text { The Times (a } \\
\text { British daily } \\
\text { newspaper) }\end{array}$ \\
\hline \multirow{2}{*}{$\begin{array}{l}\text { English, } \\
\text { Korean, } \\
\text { Chinese }\end{array}$} & \multirow{2}{*}{ Korean } & $\begin{array}{c}\text { English word + Sino- } \\
\text { Korean affix + Korean } \\
\text { affix }\end{array}$ & 15 & $\begin{array}{l}\text { 컴퓨터화하다 [keom- } \\
\text { pyu-teo-hwa-ha-da] }\end{array}$ & to computerize \\
\hline & & $\begin{array}{c}\text { English word + Sino- } \\
\text { Korean affix + Korean } \\
\text { affix } \\
\end{array}$ & 16 & $\begin{array}{l}\text { 슬림화되다 [seul-lim- } \\
\text { hwa-doe-da] }\end{array}$ & to become slim \\
\hline
\end{tabular}

Ahn (2018) rightly suggested that in the borrowing process, English words undergo creative and innovative word-formation processes, which is supported by the data presented in Table 4. However, the degree of hybridity and creativity of English loanwords is much less in the present data compared to that of Ahn (2018), as the latter included data sources involving more casual and informal language. 
Nevertheless, the data presented in Table 4 still seem complex, as the classification includes the transcription system as a criterion. While the influence of Chinese seems minimal in terms of the transcription system in the above classification, the combinations of lexical elements suggest that Sino-Korean words or affixes have a much greater productive power than pure Korean words or affixes in the English borrowing process, at least in the language of this genre and type.

This classification is not intended to systematically model English lexical borrowing, as in Ahn (2018), but to generally understand the forms and characteristics of Anglicisms in a formal written language, such as journalistic media texts, by descriptively categorizing them. Therefore, only a few examples presented in Table 4 are further investigated in detail as special cases of interest. Example 1 in the table above is often the case with technical terms or newly introduced concepts, as in MMF. Examples 6-7 and 15-16 feature the Korean derivative suffixes -ha-da and -doe-da, used to produce hybridized Anglicisms. Examples 15-16 are variations of 6-7, with a Sino-Korean particle added between English and Korean elements. They are all productive forms of incorporating English nouns and adjectives into the Korean lexis. These are further discussed along with synchronic and diachronic analyses of the corpora in Subsection 4.2.3.

\subsubsection{Diachronic changes in the use of Anglicisms}

This subsection presents the examination of the frequency of Anglicisms in the TT and OT corpora and its changes between the two periods. First, the frequency of Anglicisms was counted by creating a word list in order of frequency using WordSmith (Version 7; Scott, 2016), a linguistic analysis tool, for each corpus. The types and tokens of Anglicisms and their ratios to the total are shown in Table 5.

Table 5. Frequency and ratio of Anglicisms in the corpus

\begin{tabular}{ccccc}
\hline Statistics & TT_Kor_1 & TT_Kor_2 & OT_Kor_1 & OT_Kor_2 \\
\hline Total tokens & 54,654 & 72,642 & 67,251 & 62,998 \\
Anglicism tokens (ratio) & $5,826(10.66 \%)$ & $8,485(11.68 \%)$ & $4,391(6.53 \%)$ & $6,636(10.53 \%)$ \\
Total types & 25,193 & 29,524 & 29,764 & 25,091 \\
Anglicism types (ratio) & $3,489(13.85 \%)$ & $4,526(15.33 \%)$ & $2,555(8.58 \%)$ & $3,220(12.83 \%)$ \\
\hline Note: TT, translated texts; OT, original texts. & & & &
\end{tabular}

In the above results, the different sizes of the four corpora should be considered in terms of absolute frequency, but the ratio is a meaningful index for comparing the corpora. The proportion of Anglicisms was higher in TT than in OT, and in the recent data than in the past data. Both translated and original Korean texts showed a diachronic increase in Anglicisms between the two periods in tokens as well as types, but the increase was much larger in OT. The tokens of Anglicisms in OT increased by $4.00 \mathrm{pp}$, much greater than the $1.02 \mathrm{pp}$ increase in TT. In terms of types, OT showed a higher increase of $4.25 \mathrm{pp}$ than TT. One reason for this difference between TT and OT can be the inherent characteristic of the translated version of Newsweek. Newsweek's Korean version mainly included articles on US or international issues, so the frequency of foreign-origin words must be inevitably higher in TT than in OT, regardless of the period, leading to a smaller diachronic increase.

The above results can be compared with the findings of Jung et al. (2005, pp. 188-189), in which the frequency and ratio of English loanwords in original Korean writings in the 1970s, 1980s, and 1990s were examined. The increase in the frequency of Anglicisms over the 20 years was less than 0.4 pp, much smaller than the 1 to $4 \mathrm{pp}$ change found in the present study. As discussed earlier, this can be attributed to the social atmosphere in the 1970s through the 1990s, when there was still a significant 
presence of Chinese language ideology. The advent of globalization and technological advances that enabled free and extended language exchange had not yet occurred in this period. Another reason for the difference could be the type of corpus composed by Jung et al. (2005). They compiled a general corpus of texts sampled from various genres and types, unlike the present study that targeted only journalistic texts. They contended that journalistic and technical texts contain more Anglicisms than texts of other genres and types. Indeed, in the present study, the past OT showed an Anglicism ratio of $6.53 \%$, higher than the $1.923 \%$ found by Jung et al. in their 1990s data. This supports the argument that journalistic texts are much more receptive to Anglicisms than Korean texts in general. Moreover, this suggests that in a diachronic analysis, the corpus should be carefully designed in terms of the variety and quantity of texts to properly reflect the actual change in language use. Thus, the present study's corpus, composed of homogeneous texts, likely serves as a reliable source to observe the change in the use of Anglicisms.

\subsubsection{Anglicisms created through combinations of English and pure Korean}

According to the data presented in Table 4, the two Korean suffixes -ha-da and -doe-da are the only pure Korean elements used to create hybrid Anglicisms included in the news magazine articles examined here. Therefore, it is worth analyzing their usage in detail. In the Korean language, -ha-da and -doe-da are derivative suffixes, which are used to create verbs or adjectives by combining them with nouns, adjectives, or adverbs. They are highly productive suffixes that have also been frequently used to create Anglicisms by blending them with English nouns, adjectives, and even verbs (Ko \& Koo, 2008, pp. 226-227).

After the word list of each corpus was generated, all instances of hybrid Anglicisms with either of the two suffixes, including their conjugated forms, were identified and counted. For comparison, their frequencies were normalized per 100,000 words because of the difference in corpus size. Table 6 shows the tokens, their normalized frequencies (NF) in parentheses, and the types of Anglicisms with ha-da or -doe-da.

Table 6. Frequency of Anglicisms with -ha-da and -doe-da in TT and OT

\begin{tabular}{ccccc}
\hline Statistics & TT_Kor_1 & TT_Kor_2 & OT_Kor_1 & OT_Kor_2 \\
\hline Total tokens & 54,654 & 72,642 & 67,251 & 62,998 \\
English + - $h a$-da tokens (NF) & $19(34.76)$ & $32(44.05)$ & $7(10.41)$ & $25(39.68)$ \\
English + -doe-da tokens (NF) & $5(9.15)$ & $8(11.01)$ & $1(1.49)$ & $7(11.11)$ \\
Total types & 25,193 & 29,524 & 29,764 & 25,091 \\
English + - $h a-d a$ types & 17 & 20 & 7 & 21 \\
English + -doe-da types & 5 & 7 & 1 & 6 \\
\hline Note: TT, translated texts; OT, original texts; NF: normalized frequencies. & & &
\end{tabular}

The above results show that there were more cases of combinations of English words and the Korean derivative suffixes $-h a-d a$ and $-d o e-d a$ in TT than in OT, and in the recent data than in the past data, which is consistent with the earlier finding of all occurrences of Anglicisms. However, the actual frequencies of some items in the table are five or less, so these results should be interpreted cautiously, as the conversion into NF may have slightly distorted the data. Further, there were much more combinations of English words with -ha-da than those with -doe-da. This was a common phenomenon in both TT and OT, and in both the past and recent corpora, reaffirming that -doe-da, as a suffix, has relatively lower productivity than $-h a-d a$ (Ko \& Koo, 2008, p. 226), even when combined with 
English. Examining the unique instances of Anglicisms indicated that in the past corpus, Anglicisms were much more diverse in TT than in OT, but in the recent corpus, the frequency of the different types was almost the same between the two datasets even with different corpus sizes. (The counts were not normalized as some of the types were used repeatedly.) This implies that the Korean language community became much more receptive toward English in the latter period compared to the former.

The English words coupled with $-h a-d a$ or $-d o e-d a$ belonged to different word classes, including nouns, verbs, and adjectives. Interestingly, there were cases where two English words with the same root but different word classes competed against each other over the 20 years for being incorporated into the mainstream of the Korean lexis. Regarding Anglicisms related to the word "irony," in the past data, 아이러니컬하다 [a-i-leo-ni-keol-ha-da] (ironical + -ha-da) was found to be the unique type in both TT and OT, while in the recent data, there were also occurrences of 아이러니하다 [a-i-leo-ni-hada] (irony $+-h a-d a$ ) in OT. This suggests that the borrowability of Anglicisms can vary over time. Today, both words are included in the Standard Korean Dictionary compiled by the National Institute of Korean Language (NIKL), although the Korean transcription of the former has partly changed. A rough Google search showed that the latter is much more dominant than the former.

\subsubsection{Explanatory approach to reasons for increased use of Anglicisms}

Anglicisms were found to be more frequently used in TT than in OT, regardless of the period. This may be partly because of the existence and influence of ST. In English-to-Korean translation, there is a relatively high possibility that English lexical items from ST are written in English or transliterated, especially when they denote new technologies or concepts whose equivalents are difficult to find in the Korean language. However, the diachronic increase in Anglicisms was larger in OT than in TT. As original Korean texts do not have any ST, it would be reasonable to assume that other factors such as sociolinguistic and environmental factors, influenced the borrowing process, as noted earlier in Figure 2.

Although translators were influenced by the same social and environmental factors as other members of Korean society during the study period, the increase in Anglicisms over time was nevertheless much greater in OT. This can be attributed to not only the existence of ST but also the difference between translators and authors in terms of their choice and processing of lexical items for text production. In fact, translators tend to be more conscious of the nature and purpose of language output than non-translators because they are supposed to continuously switch between two languages when translating every lexical item, sentence, paragraph, and even text. As claimed in the functional theory of translation (Nord, 2018), translators must consider whether their deliverables can achieve their original purpose and function when working on translations. For example, they need to judge whether the functional equivalent of a word should be an Anglicism, a Korean word, or even an expanded phrase. Furthermore, to produce outputs that sufficiently meet the needs of readers and the genre or type of text, they need to consider how much foreignness to retain in the translation, which involves deciding between domestication and foreignization as a translation strategy (Venuti, 2008). Such deliberation is necessary for any kind of translation and is unlikely to have changed significantly over time. Overall, mainly the primary and tertiary causes presented in Figure 2-the nature of text and translation, stakeholders of translation, educational or experiential background as translators, etc.- may have contributed to the present results.

However, Anglicisms did indeed increase diachronically in both TT and OT. Apart from their conscious choices of lexical items, like other members of society, translators too are fundamentally influenced by language contact and change outside the translation context. As noted in Figure 2, the main influential factor in this extra-textual context is globalization, which promotes Englishization. Cronin (2013, pp. 491-492) argued that there are three aspects of modern globalization. The first is the 
epistemic aspect of the world being a united one; the second is that of the emergence of transnational institutions such as the United Nations, the World Bank, and the World Trade Organization; and the third is that of economic activity based on global connectivity. The final aspect highlights how production and distribution activities are coordinated and implemented at the global level, especially with advances in information technology. This is also true for information production and dissemination. More information needs to be translated quickly in the process of globalization; it is translated for sharing, but simultaneously, it is also shared in almost real-time without translation. However, as Cronin stated, "one of those globalizing processes is translation and globalization is quite literally unthinkable without the operation of translation and translators" (Cronin, 2013, p. 491); all language users, including translators, have been influenced by the wave of globalization, which entails the rise of English as the world's official language or a lingua franca. Meanwhile, Korea has witnessed the establishment of English as a linguistic ideology, accelerating Englishization in economic, social, and cultural terms. In the 2000s, there was a heated debate over the designation of English as an official language in Korea (Kim, 2004). Amid all these changes toward an English-friendly environment, language speakers' (including translators) linguistic attitude toward and use of English has been greatly influenced.

The presence of English ideology in Korea was also confirmed by the results of the national language awareness survey-People's Sense of Language in 2010 (Yang et al., 2010, pp. 92-94). More than half (52.5\%) of the respondents answered "somewhat unavoidable" to a question about the increase in the use of English, and 19.6\% responded "it doesn't matter," showing that more than 70\% of the respondents were positive or at least neutral to the foreign elements incorporated into the Korean language. Going beyond mere acceptance, $35 \%$ responded favorably to the question about English users, choosing positive evaluations such as "those who use English words or expressions look sophisticated" and "those who use English words or expressions look highly educated"; this was more than the $34.8 \%$ of neutral answers, such as "I feel nothing particular." In addition, $63 \%$ of the respondents said, "English education should start at an earlier age than now." Compared to the results of a previous survey in 2005 (Yang, 2005), there was a stronger social atmosphere and linguistic attitude of respecting and promoting English in 2010. As discussed so far, the globalization trend and English ideology in Korean society have been the primary causes for English borrowing in Korea, leading to changing attitudes and perceptions of English and more intense Englishization. These factors subsequently influenced language users, including translators, at the individual level. However, the linguistic behavior of using Anglicisms is the outcome of a much more complex process. There has also been resistance against English ideology, Englishization, and the use of Anglicisms (Park, 2009), which has, along with other factors associated with the translation process, decelerated the borrowing process. This is further discussed, together with the analysis of two examples of Anglicisms and its implications, in the next section.

\subsection{Analysis of two high-frequency words and their Anglicisms}

The quantitative and qualitative features of texts stem from authors' or translators' linguistic and textual decisions. Anglicisms can effectively show authors' and translators' linguistic awareness and attitude toward English because the features of the original English words are transferred almost entirely onto Anglicisms. This section presents the investigation of translators' choices and decisions about Anglicisms through an analysis of the translated expressions for two high-frequency words in ST. Subsequently, it presents a comparison between TT and OT, both synchronically and diachronically. Lastly, the implications of the analysis results are discussed. 


\subsubsection{High-frequency English words and Anglicisms in translation- "business" and "system"}

First, the word lists of ST_Eng_1 and ST_Eng_2 were generated. The words in each list were ranked by frequency to identify the most frequently used English nouns that were also included in the purified Korean word list for loanwords available on NIKL's website (The National Institute of Korean Language, n.d.). This recommendation of purified words was provided to address the concern that Koreans are using loanwords or foreign expressions unnecessarily or excessively, even when Korean alternatives are available. These loanwords targeted for purification suit the purpose of studying the lexical options available to translators and their final decisions between Anglicisms and Korean expressions. Words that met the above conditions were double-checked to ensure that they appeared in both ST_Eng_1 and ST_Eng_2. Subsequently, their related Anglicisms were checked in both TT_Kor_1 and TT_Kor_2 to determine whether translators actually used them. After these filtering steps, "business" and "system," the top two frequently used words, were selected for analysis.

Next, for all instances of the two words in the ST corpus, the corresponding translated expressions were identified in the TT corpus, excluding instances of proper nouns. The translated expressions were then classified into four types: Anglicism, headword/purified word (recommended by NIKL), other semantic translations (including paraphrasing), and omission (zero translation). The translations of "business" identified in TT_Kor_1 and TT_Kor_2 are classified in Table 7.

Table 7. Translations of "business" in TT_Kor_1 and TT_Kor_2

\begin{tabular}{ccc}
\hline Translation type & \multicolumn{2}{c}{ Frequency } \\
\cline { 2 - 3 } Anglicism & $3(6.38 \%)$ & Recent \\
\hline Headword/Purified word & $35(74.47 \%)$ & $47(67.1 \%)$ \\
Other semantic translations & $8(17.02 \%)$ & $9(12.9 \%)$ \\
Omission & $1(2.13 \%)$ & $7(10 \%)$ \\
\hline Total $:$ TT, translated texts. & 47 & 70 \\
\hline
\end{tabular}

In the past data, there were three instances of Anglicisms, while in the recent data, there were seven occurrences. The counts for other types of translation were also higher in the recent data, but this is largely due to the difference in the number of observations between the two datasets. It is clear that Anglicisms accounted for only a small proportion of the total instances. Examining the data in detail suggests that semantic translations, including headwords, purified words, and others, were chosen in various contexts, denoting diverse meanings, including "management," "economic cycle," "transaction," "company," and "work." The English word "business" has numerous Korean counterparts or purified words, reflecting its abundant connotations in English. There are thus varied options available to translators for the word "business." From this long list of options, translators may have chosen the one closest to the original meaning in a specific context.

An Anglicism of "business" (비즈니스 [bi-jeu-ni-seu]) is included in NIKL's purified Korean word list with recommended Korean alternatives. However, as shown in Table 7, it was not frequently used in the Korean version of Newsweek. Therefore, it makes little sense to examine the diachronic change in its frequency; however, there are some interesting findings that should be noted here. The Anglicism 비즈니스 was used alone or together with other Anglicisms, as in 비즈니스 스쿨 [bi-jeuni-seu seu-kul] (business school) and 비즈니스 모델 [bi-jeu-ni-seu mo-del] (business model). "Business school" was translated into the Anglicism 비즈니스 스쿨 [bi-jeu-ni-seu seu-kul] in the 
recent data, while a Sino-Korean word 경영대학원 [gyeong-yeong-dae-hag-won] meaning "a graduate school of business administration" was used for it in all instances in the past data. Such changes may have influenced the diachronic increase in Anglicisms in the translated Korean corpus. However, when the overall types of translation were considered, it was clear that Korean expressions were preferred as translation options for "business." Because "business" has many connotations, there may have been a tendency to convey its meaning with a more accurate and explicit Korean expression for native readers. In other words, translators' choice depends on not only the semantic properties of the vocabulary item but also the characteristics and purpose of the genre or type of text.

Next, the other high-frequency word "system" was analyzed. Table 8 summarizes the results of this analysis.

Table 8. Translations of "system" in TT_Kor_1 and TT_Kor_2

\begin{tabular}{ccc}
\hline \multirow{2}{*}{ Translation type } & \multicolumn{2}{c}{ Frequency } \\
\cline { 2 - 3 } & Past & Recent \\
\hline Anglicism & $21(42 \%)$ & $30(47.6 \%)$ \\
Headword/Purified word & $13(26 \%)$ & $26(41.3 \%)$ \\
Other semantic translations & $11(22 \%)$ & $4(6.3 \%)$ \\
Omission & $5(10 \%)$ & $3(4.8 \%)$ \\
\hline Total & 50 & 63
\end{tabular}

As shown in Table 8, there were 21 Anglicisms in the past data and 30 in the recent data. Compared to the translations of "business," the proportion of Anglicisms used for "system" was higher in both the past and recent data. There was a difference in the transcription of these Anglicisms between the two periods. In the past data, 시스팀 [si-seu-tim] was the standard transcription, while in the recent data, it was 시스템 [si-seu-tem], which reflects a change in language norms between the two periods. In the past data, all but 3 of the 21 Anglicisms occurred in the context of information technology. On the other hand, in the recent data, the Anglicisms appeared not only in the context of information technology but also in economic, business, social, political, and educational contexts. This suggests that the influence of Anglicisms, first introduced and used in limited areas in the past, gradually expanded to other areas over time.

Regarding headword/purified word and other semantic translations, the two datasets showed similar patterns. However, the semantic translations of "system" were relatively narrow compared to the case of "business," indicating that there may have been less ambiguity in meaning when using an Anglicism of "system" compared to when using one of "business." Anglicisms can thus be used as an effective translation solution for "system". This is supported by the significant difference found in the proportion of Anglicisms used for the two words, regardless of the period.

In addition, an abbreviation was also used to translate "system," which was not the case for "business." The term "operating system" was translated into an English initialism, OS. Such abbreviations are particularly common in the context of information technology or technical contexts. This shows that the two words differ in terms of the domain and context in which they are frequently used, which makes translators come up with differentiated translation solutions.

\subsubsection{High-frequency English words and Anglicisms in original texts- "business" and "system"}

The use of Anglicisms of "business" and "system" in OT compared to TT was examined to ascertain whether translators use Anglicisms to a similar degree as non-translators in original Korean 
texts of the same genre, or whether they tend to use more Anglicisms due to translation-related factors. To determine the frequency and context of use, Key Word in Context (KWIC) lists for the two Anglicisms 비즈니스 and 시스템 (or 시스팀) were generated from the past and recent data of the original Korean corpus.

In OT_Kor_1, the Anglicism of "business" was not used, except in one instance as part of the proper noun Business Week (an American business news magazine). In contrast, the Anglicism of "system" was used in 14 instances, excluding its use as part of 2 proper nouns; 13 of these instances were in technical contexts, except for 1 used for "publishing system." This is similar to the analysis results of TT_Kor_1. In the recent data, the frequency of Anglicisms of "business" (비즈니스) and "system" (시스템) was significantly higher-15 and 30, respectively. The contexts in which 비즈니스 was used is similar to those observed in the analysis of the translated data-company, business, management, and so forth-in both periods. The use of 시스템 showed a relatively noticeable diachronic change, as observed in the translated data. Mainly used in technical contexts in TT in the past data, 시스템 was used in other subject areas outside of technology in the recent data. Because of the difference in size between the TT and OT corpora, the NF of Anglicisms were calculated; for comparison, they are summarized in Table 9.

Table 9. Anglicisms of "business" and "system" in the TT and OT corpora

\begin{tabular}{|c|c|c|c|c|}
\hline Frequency & TT_Kor_1 & TT_Kor_2 & OT_Kor_1 & OT_Kor_2 \\
\hline Total tokens & 54,654 & 72,642 & 67,251 & 62,998 \\
\hline $\begin{array}{c}\text { "business" Anglicisms (NF)/ } \\
\text { Total translations }\end{array}$ & $3(5.49) / 47$ & $7(9.64) / 70$ & $0(0) / \mathrm{NA}$ & $15(23.81) / \mathrm{NA}$ \\
\hline $\begin{array}{c}\text { "system" Anglicisms (NF)/ } \\
\text { Total translations }\end{array}$ & $21(38.42) / 50$ & $30(41.30) / 63$ & $14(20.82) / \mathrm{NA}$ & $30(47.62) / \mathrm{NA}$ \\
\hline
\end{tabular}

The NF of Anglicisms show that 시스템 was used much more than 비즈니스 in all corpora, regardless of the period. As previously discussed, more diverse semantic translations in Korean were used for "business" than for "system," and translators tended to prefer Korean expressions that closely fit the source context. However, it is noteworthy that in the same contexts, Anglicisms of "business" were used in the recent OT, while mostly semantic translations were used in the recent TT. This indicates that compared to translators who are likely to be bilingual speakers, authors of original Korean news magazine articles, who are more likely to be monolingual, have a higher acceptance of Anglicisms. In the case of "system," the use of Anglicisms occurred in a similar pattern in both TT and OT in terms of the diachronic changes in frequency and context of use. They were used more frequently in the recent data than in the past data. Moreover, in OT, the Anglicisms of "system" were used in more diverse contexts in the recent period than in the past period.

These results reveal that lexical borrowability, as discussed by Thomason and Kaufman (1988) and Muysken (1981), according to grammatical types, is also influenced by other dimensions. Several factors, including the existence of domestic competitors, the subject and context of use, and neighboring words, can affect the probability of borrowing. Borrowability may also vary according to the text type and purpose, and depending on who is the agent of borrowing.

\subsubsection{Implications of the analysis}

The above analysis results related to the high-frequency words "business" and "system," and their translations show that the factors influencing borrowers' choices and decisions are complex. First, the 
diachronic increase in Anglicisms of both words in TT and OT seems to have mainly been affected by the spread of English ideology in Korean society and the subsequent Englishization. In particular, the fact that Anglicisms of "business" were used more frequently in the recent OT than in the recent TT explains the collective effect of such factors on the whole language community. In TT, there was a smaller diachronic increase in the use of Anglicisms of "business," and in both past and recent TT, equivalent Korean expressions suitable for specific contexts were used more frequently.

The infrequent use of Anglicisms of "business" exemplifies translators' preference for Korean, their first language, and resistance to English (Görlach, 2003), which is consistent with previous research on the borrowing of "business" (Laviosa et al., 2017, pp. 15-20). It seems more reasonable to use a Korean expression if it can better convey the original meaning, instead of borrowing the English word. Besides, when translating words with diverse connotations, such as "business," it may be more effective to use Korean expressions to convey the most accurate meaning to readers, ensuring their functional equivalence for the news magazine genre, whose main purpose is the dissemination of information to the general public.

Such an explanation, however, does not apply to all cases of English borrowing, as evident from the above examples related to the "system." Regarding "system," Anglicisms were more common than semantic translations in both TT and OT. The word "system" has a relatively narrow semantic domain compared to "business." It is often used in fields in which English is widely employed to refer to new technology or concept with no equivalent word in the Korean language, resulting in a higher borrowability of the English word. This higher acceptance led to its increased spread over the 20 years, even in fields where borrowing was not urgently necessary. Besides, the frequent use of Anglicisms in the past TT suggests that translators have a relatively higher acceptance of English for newly introduced technological or technical words for which Anglicisms are deemed necessary due to the lack of equivalent words. Lastly, the difference in borrowability of the Anglicisms of the two highfrequency words discussed here indicates that even within the same text, different translation strategies and methods can be deployed to meet the requirements of translation - such as functional equivalence, genre norms for optimal communication, and domestication or foreignization for the targeted readership. This reflects translators' efforts in managing risk for effective communication (Pym, 2008, p. 326).

\section{Conclusions}

This study analyzed the use of Anglicisms in English-to-Korean translation and original Korean texts from the perspective of language contact and change. Besides, it clarified the perceptions and decisions of translators (agents of language contact and change) regarding borrowing. Anglicisms in translated and original news magazine articles were analyzed and compared across two different periods. The key factors influencing the borrowing process were discussed in connection with the quantitative corpus analysis and specific cases of Anglicisms. The study findings can be summarized as follows.

First, Anglicisms occurred more frequently in TT than in OT. This is because the existence of a source text inherently limits a translator's choice of lexical items in the target language. Translators generally favored the use of Anglicisms if there were no Korean equivalents for unfamiliar new technologies or concepts, or if semantic translations resulted in awkward language. Second, over time, the proportion of Anglicisms significantly increased in OT compared to TT, indicating that nontranslators may have become more receptive toward Englishization than translators over the 20-year period from 1991 to 2012. This is supported by the analysis of two high-frequency Anglicisms that revealed translators' concerns about or resistance toward unnecessary Englishization, as claimed in 
previous research. Translators, who are generally aware of the influence of their translations on the entire language community, are deemed more conservative or cautious about accepting and using Anglicisms in their translations. Third, the degree of acceptance of Anglicisms may vary due to various known and unknown (invisible) factors, such as English ideology; the status of Englishization; social environment; competing expressions in the receptor language; the type, genre, purpose, and function of texts; and the profile of the "borrower," be it a translator or non-translator. Regarding TT, in particular, this argument is supported by the analysis of the two Anglicisms presented here. When deciding to use Anglicisms, translators undergo a complex decision-making process considering the abovementioned factors. This indicates translators" tendency toward risk aversion (Pym, 2008) for effective communication.

In conclusion, although the frequency of Anglicisms was greater in translation than in original texts, the influence of English and receptivity to Anglicisms is not always clearer in translation than in original Korean texts, especially diachronically. This can be attributed to numerous non-linguistic or sociolinguistic factors and their complex interactions that promote or hinder contact-induced linguistic change and influence the decision-making process in translation.

The present study has three limitations. First, the study made its best efforts to build a sizable corpus despite the difficulties of compiling a DIY corpus for diachronic analysis. Considering similar prior research (House, 2011; Musacchio, 2005; Teich, 2003), its size was not small; however, in some cases, the frequencies of Anglicisms were not large enough, calling for cautious interpretation as in Table 6. Future research should consider compiling a larger corpus. Second, there was a lack of variety in the composition of the corpus. It was difficult to secure a set of ST-TT-OT media texts with a long history of publication for a diachronic study. As the study's corpus consists of a single source of ST and TT (Newsweek) and another single source of OT (Sisa Journal) in the news magazine genre, most of the analysis results and conclusions of this study can best be examined within the specific scope instead of being generalized. Third, some of the study's findings, particularly about translators' attitudes toward and acceptance of Anglicisms, were confirmed through personal communications with dozens of translators outside the scope of this study. Future research needs to consider a survey of translators, similar to NIKL's national language awareness surveys, as a way of triangulation.

Despite the limitations, this study enriches the translation studies by introducing a new contact linguistic perspective to examine the influence of English in translations compared to non-translations. It also confirms the value of empirical studies involving diachronic corpus analysis in discovering time-induced language changes. Future empirical research should conduct a further detailed investigation of the reality of language contact and change, verifying existing hypotheses and cases.

\section{References}

Ahn, H. J. (2018). Modelling the Englishization of vocabulary in contemporary Korean. World Englishes, 37(4), 570-589.

Baik, M. J. (1994). Syntactic features of Englishization in Korean. World Englishes, 13(2), 155-166.

Baratta, A. (2014). The use of English in a Korean TV drama to signal a modern identity. English Today, 30(3), 54-60.

Baumgarten, N., \& Özçetin, D. (2008). Linguistic variation through language contact in translation. In M. Rothweiler, J. House, \& P. Siemund (Eds.), Language contact and contact languages (pp. 293316). Amsterdam/Philadelphia: John Benjamins. 
Bielsa, E. (2012). Beyond hybridity and authenticity: Globalisation, translation and the cosmopolitan turn in the social sciences. Synthesis, 4, 17-35.

Bielsa, E., \& Bassnett, S. (2009). Translation in global news. New York: Routledge.

Cho, Y. H. (2014). Comparison of Korea and Japan in terms of translating American movie title. Interpreting and Translation Studies, 18(4), 274-294.

Choi, H. (2018). A corpus-based study on lexical borrowing in English-to-Korean translations of business magazine articles. Interpreting and Translation Studies, 22(1), 235-263.

Cronin, M. (2013). Translation and globalization. In C. Millán \& F. Bartrina (Eds.), The Routledge handbook of translation studies (pp. 491-502). London/New York: Routledge.

Crystal, D. (2001). Language and the Internet. Cambridge: Cambridge University Press.

Crystal, D. (2003). English as a global language. Cambridge: Cambridge University Press.

Crystal, D. (2008). A dictionary of linguistics and phonetics (6th ed.). Oxford: Blackwell Publishing.

Dalby, A. (2004). Dictionary of languages. London: A \& C Black.

De Saussure, F. (1966). Course in general linguistics (W. Baskin, Trans. C. Bally \& A. Sechehaye Eds.). New York/Toronto/London: McGraw-Hill.

Fairclough, N. (1989). Language and power. London/New York: Longman.

Fine, G. A., \& Sandstrom, K. (1993). Ideology in action: A pragmatic approach to a contested concept. Sociological Theory, 11(1), 21-38.

Gellerstam, M. (2005). Fingerprints in translation. In G. Anderman \& M. Rogers (Eds.), In and out of English: For better, for worse? (pp. 201-213). Clevedon: Multilingual Matters.

Gómez-Rendón, J. A. (2008). Typological and social constraints on language contact: Amerindian languages in contact with Spanish, 1. Utrecht: LOT.

Görgülü, E. (2018). Foreignization and Englishization in Turkish business naming practices. Journal of Language and Linguistic Studies, 14(1), 139-152.

Görlach, M. (2003). English words abroad. Amsterdam/Philadelphia: John Benjamins.

Gotti, M. (2007). Globalization and discursive changes. In N. Fairclough, G. Cortese, \& P. Ardizzone (Eds.), Discourse and contemporary social change (pp. 143-172). Bern: Peter Lang.

Gottlieb, H. (2005). Anglicisms and translation. In G. Anderman \& M. Rogers (Eds.), In and out of English: For better, for worse? (pp. 161-184). Clevedon: Multilingual Matters.

Harkness, N. H. (2012). Vowel harmony redux: Correct sounds, English loanwords, and the sociocultural life of a phonological structure in Korean. Journal of Sociolinguistics, 16(3), 358381.

Hedderich, N. (2003). Language change in business German. Global Business Languages, 8, 47-55.

Hickey, R. (Ed.) (2010). The handbook of language contact. Malden, MA: Wiley-Blackwell.

Hilgendorf, S. K. (2001). Language contact, convergence, and attitudes: The case of English in Germany. Urbana: University of Illinois at Urbana-Champaign.

Holz-Mänttäri, J. (1984). Translatorisches handeln: Theorie und methode. Helsinki: Suomalainen Tiedeakatemia. 
House, J. (2011). Using translation and parallel text corpora. In A. Kruger, K. Wallmach, \& J. Munday (Eds.), Corpus-based translation studies: Research and applications (pp. 187-208). London/New York: Continuum.

Jung, K. T. (1998). Contact and convergence of English in Korea. (Unpublished doctoral dissertation), The University of Illinois at Urbana-Champaign, Illinois.

Jung, K. T. (2001). Englishization in advertising in Korea. The Journal of Modern British \& American Language \& Literature, 19(3), 91-107.

Jung, Y. C., Lee, S. D., Kim, I. T., Kim, E. I., Jho, G. H., Kim, J. Y., \& Kim, S. J. (2005). A diachronic study of the linguistic-cultural influence of English on Korean. The New Korean Journal of English Language \& Literature, 47(1), 185-225.

Kachru, B. B. (1990). World English and applied linguistics. World Englishes, 9(1), 3-20.

Karakaş, A. (2017). Students' perceptions of 'Good English' and the underlying ideologies behind their perceptions. Journal of Language and Linguistic Studies, 13(2), 487-509.

Kim, C. J. (2009). Problems of rendering Sino-Korean words under the Hangul-only system. HACE, 23, 187-212.

Kim, E. J. (2016). Anglicized Korean neologisms of the new millennium: An overview. English Today, 32(3), 52-60.

Kim, H. Y. (2008). A semantic approach to the translation of English loanwords into Korean in the period of the late 19th and early 20th centuries. Korean Journal of Linguistics, 33(3), 457-480.

Kim, K. I. (2004). How to make English public language in Seoul: Some suggestions to increase Seoul population's cultural flexibility and familiarity with English. Seoul Studies, 5(1), 119-144.

Kim, S. W., \& Kim, J. W. (2011). The translation types and methodology of technical terms-With a special reference to medical ones. The Journal of Translation Studies, 12(2), 34-52.

Kim, W. S. (2006). Loanwords in the media. Language and Linguistics, 37, 49-66.

Ko, Y. K., \& Koo, B. K. (2008). Urimal munbeomnon [The Korean grammar]. Paju: Jipmoondang.

Kvaran, G. (2004). English influence on the Icelandic lexicon. Nordic Journal of English Studies, 3(2), $143-152$.

Laviosa, S. (2002). Corpus-based translation studies: Theory, findings, applications. Amsterdam: Rodopi.

Laviosa, S., Pagano, A., Kemppanen, H., \& Ji, M. (2017). Textual and contextual analysis in empirical translation studies. Singapore: Springer.

Lee, J. S. (2014). English on Korean television. World Englishes, 33(1), 33-49.

Matras, Y. (2010). Contact, convergence, and typology. In R. Hickey (Ed.), The handbook of language contact (pp. 66-85). Malden, MA: Wiley-Blackwell.

Millar, N. (2009). Modal verbs in TIME - Frequency changes 1923-2006. International Journal of Corpus Linguistics, 14(2), 191-220.

Musacchio, M. T. (2005). The influence of English on Italian: The case of translations of economics articles. In G. Anderman \& M. Rogers (Eds.), In and out of English: For better, for worse? (pp. 71-96). Clevedon: Multilingual Matters. 
Muysken, P. (1981). Half-way between Spanish and Quichua. The case for relexification. In A. Highfield \& A. Valdman (Eds.), Historicity and change in creole studies (pp. 52-78). Ann Arbor: Karoma.

Nelde, P. H. (1992). Ethnolinguistic minorities within the European community: Migrants as ethnolinguistic minorities. In E. H. Jahr (Ed.), Language contact: Theoretical and empirical studies (pp. 131-148). New York: Mouton de Gruyter.

Nord, C. (2018). Translating as a purposeful activity: Functionalist approaches explained. London/New York: Routledge.

Oh, M. (2012). Adaptation of English complex words into Korean. Journal of East Asian Linguistics, 21, 267-304.

Park, J. S. Y. (2009). The local construction of a global language: Ideologies of English in South Korea. Berlin/New York: Mouton de Gruyter.

Pennycook, A. (2009). English and globalization. In J. Maybin \& J. Swann (Eds.), The Routledge companion to English language studies (pp. 113-121). London/New York: Routledge.

Pym, A. (2008). On Toury's laws of how translators translate. In A. Pym, M. Shlesinger, \& D. Simeoni (Eds.), Beyond descriptive translation studies: Investigations in homage to Gideon Toury (pp. 311328). Amsterdam/Philadelphia: John Benjamins.

Ryu, H. J. (2007). Transliteration and gloss in the translation of cybertext. The Journal of Translation Studies, 8(1), 107-124.

Sankoff, G. (2001). Linguistic outcomes of language contact. In P. Trudgill, J. Chambers, \& N. Schilling-Estes (Eds.), Handbook of sociolinguistics (pp. 638-668). Oxford: Basil Blackwell.

Scott, M. (2016). WordSmith Tools (Version 7) [Computer software]. Stroud: Lexical Analysis Software.

Siemund, P. (2008). Language contact: Constraints and common paths of contact-induced change. In M. Rothweiler, J. House, \& P. Siemund (Eds.), Language contact and contact languages (pp. 311). Amsterdam/Philadelphia: John Benjamins.

Silverstein, M. (1979). Language structure and linguistic ideology. In P. R. Clyne, W. F. Hanks, \& C. L. Hofbauer (Eds.), The elements: A parasession on linguistic units and levels (pp. 193-247). Chicago: Chicago Linguistic Society.

Teich, E. (2003). Cross-linguistic variation in system and text. New York: Mouton de Gruyter.

Teich, E. (2009). Translation as a linguistic variation. Paper presented at the Symposium "Towards an empirical theory of translation", Saarbrücken, Germany.

The National Institute of Korean Language. (n.d.). Dadeumeun mal [The purified Korean word list for loanwords]. Retrieved October 20, 2020, from https://www.korean.go.kr/front/imprv/refine List.do?mn_id=158.

Thomason, S. G. (2001). Language contact: An introduction. Edinburgh: Edinburgh University Press.

Thomason, S. G., \& Kaufman, T. (1988). Language contact, creolization, and genetic linguistics. Berkeley: University of California Press.

Trask, R. L., \& Stockwell, P. (2007). Language and linguistics: The key concepts. New York: Routledge. 
Venuti, L. (2008). The translator's invisibility. New York: Routledge.

Winford, D. (2003). An introduction to contact linguistics. Oxford: Blackwell Publishing.

Wollin, L. (2002). Nordic language history and the history of translation II: Swedish. In O. Bandle, K. Braunmüller, E. H. Jahr, A. Karker, H.-P. Naumann, \& U. Telemann (Eds.), The Nordic languages: An international handbook of the history of the North Germanic languages, 1, pp. 511518). New York: Walter De Gruyter.

Yang, J. H., Yang, S. Y., Shin, S. H., Lee, S. J., \& Ahn, S. J. (2010). People's sense of language in 2010. Seoul: The National Institute of Korean Language.

Yang, M. H. (2005). People's sense of language in 2005. Seoul: The National Institute of Korean Language.

\section{AUTHOR BIODATA}

Heekyung Choi is an assistant professor in the Department of English for International Conferences and Communication at Hankuk University of Foreign Studies. Her main research interests include translation as a mode of language contact, corpus-based translation studies, and the style of translation. 